\title{
Social protection as a strategy to address climate-induced migration
}

\author{
Susanne Schwan and Xiaohua Yu \\ Department of Agricultural Economics and Rural Development, \\ University of Goettingen, Goettingen, Germany
}

\begin{abstract}
Purpose - This paper aims to discuss the roles of social protection in reducing and facilitating climateinduced migration. Social protection gained attention in the international climate negotiations with the establishment of the Warsaw International Mechanism for Loss and Damage. Yet, its potential to address migration, considered as a key issue in the loss and damage debate, has not been sufficiently explored. This paper aims at identifying key characteristics of social protection schemes which could effectively address climate-induced migration and attempts to derive recommendations for policy design.

Design/methodology/approach - Based on the existing literature, the paper links empirical evidence on the effects of social protection to climate-related drivers of migration and the needs of vulnerable populations. This approach allows conceptually identifying characteristics of effective social protection policies.

Findings - Findings indicate that social protection can be part of a proactive approach to managing climateinduced migration both in rural and urban areas. In particular, public work programmes offer solutions to different migration outcomes, from no to permanent migration. Benefits are achieved when programmes explicitly integrate climate change impacts into their design. Social protection can provide temporary support to facilitate migration, in situ adaptation or integration and adaptation in destination areas. It is no substitution for but can help trigger sustainable adaptation solutions.
\end{abstract}

Originality/value - The paper helps close research gaps regarding the potential roles and channels of social protection for addressing and facilitating climate-induced migration and providing public support in destination, mostly in urban areas.

Keywords Displacement, Adaptation, Climate change, Migration, Human mobility, Social protection

Paper type Research paper

\section{Introduction}

There is a broad consensus that climate change will affect human migration in different ways (Adger et al., 2014; Black et al., 2011; Foresight, 2011; Ionesco et al., 2017; Obokata et al., 2014; Piguet, 2012; Tacoli, 2009; Warner and Afifi, 2014). Substantial evidence suggests that planning for and facilitation of migration can reduce future costs and increase human security (Adams and Adger, 2013; Adger et al., 2014; Ionesco et al., 2017). But climate-induced migration remains insufficiently addressed. Concrete policy instruments to

(C) Susanne Schwan and Xiaohua Yu. Published by Emerald Publishing Limited. This article is published under the Creative Commons Attribution (CC BY 4.0) licence. Anyone may reproduce, distribute, translate and create derivative works of this article (for both commercial \& noncommercial purposes), subject to full attribution to the original publication and authors. The full terms of this licence may be seen at http://creativecommons.org/licences/by/4.0/legalcode 
IJCCSM 10,1

manage migration are still lacking (Adams and Adger, 2013; Felgentreff and Geiger, 2013; ODI, 2016; Tacoli, 2009). Empirical evidence on innovative social protection programmes demonstrates that it can play an important role in addressing the root causes of and in facilitating climate-induced and rural-urban migration. Strengthening and "climateproofing" existing social protection programmes can be more effective than implementing new climate-specific programmes (Coirolo et al., 2013).

Based on conceptual arguments and empirical literature on climate-induced migration and social protection, this paper explores the roles social protection can play in reducing and facilitating migration due to climate change. Being a relatively young field of research, empirical evidence on the potential benefits of social protection programmes to address climate-induced migration is very limited. This paper attempts to fill the research gap by analysing empirical literature on the effects of innovative social protection programmes and linking them to climate-related drivers of migration and the needs of vulnerable populations. This allows conceptually deriving key policy implications for the design of future policies.

A number of studies already mentioned social protection as a potential means to climate change adaptation (Béné et al., 2014; Coirolo et al., 2013; Foresight, 2011; Johnson, 2009; Johnson and Krishnamurthy, 2010; Kuriakose et al., 2013; Martin, 2013; Panda, 2013; Paul and Routray, 2011; Subbarao et al., 2013; Weldegebriel and Prowse, 2013). The topic further gained attention in the international climate negotiations with the introduction of the Warsaw International Mechanism for Loss and Damage. The initial two-year work plan of the mechanism aims at enhancing the understanding of social protection as an instrument to address loss and damage associated with climate change in which migration is a key aspect (UNFCCC, 2014). Most recently, the indicative framework for the five-year workplan of the Warsaw International Mechanism outlines social protection as part of comprehensive risk management approaches, one of its indicative strategic workstreams (UNFCCC, 2016b).

However, to the best of the authors' knowledge, no research has yet thoroughly analysed the potential role and channels of social protection for addressing climate-induced migration. In particular, there is a research gap concerning the facilitation of migration and public support for migrants in destination areas. Most studies and policy responses, if in the least addressing migration, focus on measures to prevent or reduce migration. This is of course an important aspect but can also entail detrimental consequences for human security and development in the long-term (Foresight, 2011; Gemenne, 2011; Martin, 2013; Tacoli, 2009). A key requirement for an effective strategy is to address the different stages - before, during and after - and different outcomes of climate-induced migration: no, temporary or permanent movements (UNFCCC, 2016a). The diversity of migration outcomes across time, distance and context makes it difficult to implement one single approach (Gomilova, 2016; Gray and Wise, 2016).

Johnson and Krishnamurthy (2010), one of the rare papers focusing on the role of social protection to address migration, analysed how social protection programmes can facilitate economic, predominantly international migration as a means to climate risk management. Building on the existing research, this paper demonstrates that social protection, or more specifically public work programmes, can play various roles in a national policy framework addressing migration due to climate change. In addition to the provision of transfers, public work programmes can generate direct adaptation benefits through the assets and infrastructure constructed as part of these programmes. To explore the benefits of social protection programmes for adaptation or more specifically for climate-induced migration, this paper focuses on two social protection schemes recognized for their innovative design and substantial potential to address climate change: the Indian Mahatma Gandhi National 
Rural Employment Guarantee Act (NREGA) and the Ethiopian Productive Safety Net Program (PSNP).

This paper is structured as follows:

- Chapter 2 provides an overview over the effects of climate change on human migration and over migration as an adaptation strategy;

- Chapter 3 reviews empirical evidence on the benefits of the aforementioned social protection programmes;

- Chapter 4 analyses how social protection can address migration associated with climate variability and change; and

- Chapter 5 concludes with policy recommendations and future research needs.

\section{Human migration and the effects of climate change}

The identification of the different roles social protection can play in addressing climateinduced migration requires an understanding of prevalent types of migration and how these are affected by climate change. This section briefly outlines how migration is understood in this paper and gives an overview of the nexus between climate change and human migration. It sets up the foundation for further analysis.

\subsection{Understanding of migration}

Migration, in a broader sense, refers to voluntary or involuntary relocation. The latter is more precisely termed as displacement (Foresight, 2011). While internal migrants stay within their country of origin, international migrants cross a national border. Both internal and international migration can be permanent or temporary. The same distinctions apply to internally and externally displaced persons, who are forced to flee their place of origin due to armed conflict, violations of human rights, natural or man-made disasters (IOM, 2004).

Other terms used in the literature are distress or survival migration and economic or investment migration. Migration due to climate-related slow-onset changes may be voluntarily in prospect of better livelihood opportunities (economic migration), while extreme-weather events often cause forced displacement (distress migration) (Johnson and Krishnamurthy, 2010; Kleemans, 2015). In the context of climate change, distress migration is often a last resort "when adaptation efforts are unable to provide an acceptable level of security from risks" (Klein et al., 2014, p. 919). Acknowledging the difference between voluntary migration and forced displacement in respect of their causes and required response, this paper refers to migration in its broader sense if not stated otherwise.

The explicit focus is on internal migration as the majority of human mobility occurs within national borders (Adger et al., 2014; De Weerdt and Hirvonen, 2013; Foresight, 2011; Gray and Mueller, 2012a; Martin, 2010). This applies to current and to projected numbers (Adger et al., 2014; Foresight, 2011; Gemenne, 2011; Tacoli, 2009). The dominance of internal migration is explained by the fact that there are barriers to migration, such as costs, uncertainty and social exclusion, which are especially related to cross-border and long-term migration (Barnett and Webber, 2010; Gray and Mueller, 2012a). The often-stated assumption that permanent international migration will increase as a result of climate change has no substantial empirical evidence (Gemenne, 2011; Gray and Wise, 2016; Tacoli, 2009).

\subsection{The climate change-migration nexus}

The nexus between climate change and human migration is still a rather young field of research. As no scientifically reliable methods to provide quantitative estimates exist to 
IJCCSM

10,1

date, projections of climate-induced migration diverge substantially. Multi-causality, the limited understanding of human behaviour and the lack of data impede reliable modelling approaches. The current approaches usually focus on exposure to climate risks under different climate scenarios. They do not analyse the interactions with human decisionmaking, demographic trends or adaptive capacities, and are thus only valid for estimating the number of people at risk but not the number of potential migrants (Adams and Adger, 2013; Barnett and Webber, 2010; Gemenne, 2011; Palmer and Smith, 2014; Piguet, 2010; Tacoli, 2009). Yet, there is a broad consensus that climate change will and already does affect different forms of human migration (Adger et al., 2014; Black et al., 2011; Felgentreff and Geiger, 2013; Foresight, 2011; Piguet, 2012; Tacoli, 2009; Warner and Afifi, 2014).

Migration has been widely used as an adaptation or coping strategy in regions exposed to climate variability (Adams and Adger, 2013; Adger et al., 2014; Black et al., 2011; Foresight, 2011; Kleemans, 2015; Kniveton et al., 2012; McLeman, 2013). For example, migration of a household member or the whole household is already a common response to drought-related yield losses and livestock mortality (Gray and Mueller, 2012b; Kelley et al., 2015; Martin, 2013), to changes in rainfall variability (Warner and Afifi, 2014) as well as to temperature anomalies (Gray and Wise, 2016). However, the decision to migrate depends on various drivers. The root causes are often difficult to define (Johnson and Krishnamurthy, 2010; Mallick and Vogt, 2014; Piguet, 2012). Economic factors, especially income disparity between rural and urban areas, are still the dominant drivers (Adger et al., 2014; Foresight, 2011; Kleemans, 2015; Kniveton et al., 2012; Revi et al., 2014). Further, migration is an integral part of development (Barnett and Webber, 2010; De Weerdt and Hirvonen, 2013; Tacoli, 2009) and would continue to increase regardless of environmental change (Foresight, 2011). Thus, although the influence of environmental drivers, including climate change, is projected to increase in the future, analysing any driver in isolation is an oversimplification (Holst et al., 2013). Other drivers include macro-level social, economic, demographic and political aspects as well as micro-level factors, such as access to capital, alternative livelihood options, social networks and human behaviour (Adams and Adger, 2013; Black et al., 2011; Foresight, 2011; Kniveton et al., 2012; McLeman, 2013; Piguet, 2012, 2013). Kniveton et al. (2012) use empirical data from Burkina Faso, as an example, and demonstrate that drier conditions cause a slight increase in future migration, which is more pronounced under scenarios of higher population growth. Their research underlines the interdependence of different drivers, in particular the non-linear impact of climate change on migration when population growth is taken into account. Climate change is thus an additional stressor interacting with other factors driving migration (Foresight, 2011; Kniveton et al., 2012; Martin, 2013; Piguet, 2012).

The most direct causes for migration associated with climate variability and change are climate-related extremes, such as droughts, floods or tropical storms (Adams and Adger, 2013; Gemenne, 2011; Martin, 2013). Only a small proportion of migration due to extreme events is permanent. The major part is temporary as most migrants eventually return to their place of origin (Adger et al., 2014; Barnett and Webber, 2010; Kleemans, 2015; Johnson and Krishnamurthy, 2010). As an example, Gray and Mueller (2012a) analyse the effects of climate-related extreme events on population mobility in Bangladesh and find that the dominant type of migration is temporary and of short distance.

The impacts of slow-onset changes, such as rising temperatures or changing rainfall patterns, have a more indirect effect on migration and are more likely to result in permanent and in some cases international migration (Adger et al., 2014; Bohra-Mishra et al., 2014; Kleemans, 2015; Martin, 2013; Foresight, 2011; Johnson and Krishnamurthy, 2010). Feng et al. (2010) provide an example: they analyse the effects of changes in crop yields as a 
consequence of climate variability on cross-border migration from Mexico to the USA. They identify a significant increase of cross-border migration and underline that similar scenarios may also be observed in other regions under changing climate conditions. In general, slowonset changes can irreversibly affect livelihoods, particularly those depending on natural resources and ecosystem services. They exacerbate resource scarcity and impair economic opportunities (Adams and Adger, 2013; Foresight, 2011; Martin, 2013). Slow-onset changes thus augment economic constraints which are identified a key factor to determine the level of adaptive capacity (Klein et al., 2014), and increase economic arguments to migrate (Adger et al., 2014; Foresight, 2011; Black et al., 2011). In contrast, slow-onset changes such as sealevel rise, land degradation and glacier retreat, which can make areas inhabitable in the longer term, are also projected to directly cause migration (Adams and Adger, 2013; Gemenne, 2011; Martin, 2013).

\subsection{Migration as an adaptation strategy}

Several studies have demonstrated that migration can be a successful adaptation strategy to counter climate risks (Jülich, 2011; Kleemans, 2015; Warner and Afifi, 2014). Migration can avoid or reduce exposure to specific risks and contributes to livelihood and income diversification (Adams and Adger, 2013; Black et al., 2011; Clarke and Dercon, 2009; Klein et al., 2014; Maystadt and Mueller, 2012; Zhao et al., 2014). It further provides an informal risk-sharing network, usually as a unilateral insurance through remittances from migrants to family members (De Weerdt and Hirvonen, 2013; Mbaye and Zimmermann, 2015; Tacoli, 2009). Migration can thus relax economic adaptation constraints (Klein et al., 2014; Black et al., 2011). However, the level of vulnerability determines whether people have a choice, are forced to migrate (Davies et al., 2009; Martin, 2013) or are even forced to stay (Adger et al., 2014; Black et al., 2011; Foresight, 2011; Warner and Afifi, 2014).

Due to incurred costs and other barriers, migration is in many cases not an option for liquidity-constrained households. In their study in Bangladesh, Gray and Mueller (2012a) find that it is not necessarily the poor who migrate most often. This is, on the one hand, due to significant adaptation capacity of rural households and, on the other hand, due to substantial economic, social and legal barriers. Migration is thus negatively correlated with vulnerability: the most vulnerable people often have the least capabilities to migrate (Adger et al., 2014; Black et al., 2011; Gray and Mueller, 2012a, 2012b; Jülich, 2011). Further, due to social and economic networks, bonds and attachment people often prefer to stay as long as adaptation is possible (Adams, 2016; Koubi et al., 2013).

Black et al. (2011) emphasize that the risk of global environmental change is the greatest for those who do not migrate due to barriers or unwillingness. Policies aiming at preventing migration may even increase this risk. Additionally, climate change through its negative impacts on household income, livelihood options and agricultural productivity can aggravate poverty and further diminish capacities to move (Warner and Afifi, 2014; Foresight, 2011; Gemenne, 2011, Gray and Mueller, 2012a). An empirical analysis in Costa Rica, as an example, shows that migration decreases after severe hydro-meteorological extremes while it increases after less severe events. This may be explained by the destruction of household assets through weather extremes and consequently, increasing migration barriers (Robalino et al., 2015). Similarly, increases in distress migration due to more frequent or more intense extreme-weather events reduce the opportunity for more profitable migration (Warner and Afifi, 2014; Kleemans, 2015). The number of people forced to stay, so-called trapped populations, may amplify under more severe climate change scenarios (Gemenne, 2011). Consequently, policy responses are needed to foster and make migration an option (Klein et al., 2014; Gemenne, 2011; Black et al., 2011). 
IJCCSM 10,1

For those having the ability and resources to use migration as an investment, income opportunities need to be sufficiently high to compensate for the costs related to relocation (Klaiber, 2014). Using empirical data from Indonesia, Kleemans (2015) analyses the effect of rainfall shocks and shows that investment migration is up to four times more expensive than distress migration. Further, it is costlier for poorer and less educated households. This underlines that distress migration usually is a strategy of relatively poorer households, while investment migration is more likely a strategy of better-off households. In Indonesia, both strategies have positive returns in terms of increased wages and consumption. However, the returns of investment migration exceed those of distress migration (Kleemans, 2015).

But the outcomes of migration are not always positive. Migration can also increase vulnerability and reinforce poverty. This is especially true for migrants settling in urban and coastal areas. These areas are often highly exposed to climate change impacts, such as floods and storms, and lack access to basic public services such as clean water, proper housing and sanitation (Adams and Adger, 2013; Adger et al., 2014; Black et al., 2011; Dercon, 2011; Foresight, 2011; Johnson and Krishnamurthy, 2010). This should concern policy-makers as the major trend in migration, climate-related or not, are movements from rural to urban areas posing major challenges to urban sustainability and climate resilience (Adams and Adger, 2013; Adger et al., 2014; Rosenzweig et al., 2011).

\section{Empirical evidence on the benefits of social protection}

Empirical research on social protection demonstrates that it can make development more sustainable and inclusive (Dercon, 2011). These are also important characteristics of the programmes aiming at enhancing adaptive capacity and managing migration. To explore migration-relevant benefits, this section briefly presents the underlying understanding of social protection and analyses the empirical evidence on two public work programmes recognized in the literature for their innovative design and potential adaptation benefits.

\subsection{Understanding of social protection}

Social protection, though a prominent strategy for poverty reduction (Berhane et al., 2014), is not clearly defined in the literature. It is understood as a broad concept referring to different measures addressing vulnerabilities of poor and marginalized people (Dercon, 2011) with the objective "to protect and promote [their] economic and social security" (Coirolo et al., 2013, p. 78). This paper understands social protection as the provision of protection, transfers, and insurance, as well as of rights and legislation empowering the disadvantaged (Gentilini and Omamo, 2011). Social protection schemes often include a range of instruments depending on the specific policy objectives. These include transfers of income, assets or food, and insurance against risks, such as illness, unemployment or disaster (Coirolo et al., 2013; Dercon, 2011; Kothari, 2014). The public employment programmes analysed in this paper have two main objectives: the provision of temporary employment and rural assets (Subbarao et al., 2013).

\subsection{Benefits of social protection}

Public employment programmes have long focused on transferring income to the poor as their main objective. Recent policy interventions link employment generation to investments in rural assets that enhance agricultural productivity and natural resource management (Hoddinott et al., 2012; Lieuw-Kie-Song, 2010). These programmes offer a promising approach to addressing the causes of poverty and food insecurity (Hoddinott et al., 2012), of 
distress and rural-urban migration (Imbert and Papp, 2014; Morten, 2015), and of the impacts of climate change (Gentilini and Omamo, 2011; Johnson et al., 2013).

By the number of beneficiaries, the NREGA is the largest cash-for-work programme in the world (Kothari, 2014; Subbarao et al., 2013). In the financial year 2014/2015, it provided employment to almost 40 million households or 58 million people (Ministry of Rural Development, Government of India, 2015). The Act, which came into force in 2006, provides a legal entitlement for rural households to up to 100 days of paid work per year. The entitlement pertains to every rural household willing to provide manual labour at the minimum wage. If work cannot be provided by local administrations within 15 days the act foresees unemployment allowances. The main objective of NREGA is to provide protection through paid employment. The long-term goal is to enhance rural livelihood security through public works that generate agricultural and environmental benefits, such as soil and water conservation and irrigation works (Ministry of Rural Development, Government of India, 2012).

Though empirical literature on NREGA is growing, quantitative studies mainly focus on price and wage effects (Deininger and Liu, 2013). Only recently, the focus has been shifted towards food security, agriculture and rural-urban migration.

The PSNP, the second programme analysed in this paper, is one of the rare large-scale social protection programmes in sub-Saharan Africa reaching about seven million beneficiaries annually (Berhane et al., 2014). Its main objective is to address food insecurity and increase resilience to drought through labour-intensive public works. It further provides direct cash and food transfers to households unable to work. Contingency funds allow increasing support in case of emergencies, such as a shortage of rainfall or food price inflation (Subbarao et al., 2013). Another innovative feature is the integration of insurance. As a pilot, the R4 Rural Resilience Initiative provides index-based weather insurance in exchange for labour (OXFAM, 2014). PSNP thus combines different instruments to address food insecurity, poverty and environmental degradation.

PSNP is probably the best-researched social protection programme globally (Subbarao et al., 2013). It has significantly improved food security among beneficiaries and reduced the selling of productive assets as a coping strategy to deal with droughts. This has been achieved despite increasing food prices and frequent drought conditions (Berhane et al., 2011; Berhane et al., 2014). It further led to an increase in livestock holdings and the value of productive assets owned by households, though these effects were only observed in some regions (Berhane et al., 2014, 2011; Subbarao et al., 2013).

Similarly, the empirical evidence on NREGA shows positive effects on average consumption and food intake (Deininger and Liu, 2013; Jha et al., 2011; Ravi and Engler, $2009,2015)$. The programme also contributes to poverty reduction of scheduled casts and tribes, a traditionally marginalized population group in India with a strong dependence on agriculture (Klonner and Oldiges, 2014). NREGA represents a substantial part of the income of agricultural labourers and small-scale farmers participating in the programme (Devi et al., 2011). However, the research on its redistributive effects remains inconclusive, with results from different empirical methods ranging from small wage decreases to substantial increases in rural labour markets (Zimmermann, 2013). The empirical evidence further indicates that NREGA reduces uncertainty and increases the probability of rural households to save (Ravi and Engler, 2009). Both effects have the potential to increase adaptive capacities and to reduce the pressure to migrate.

Improvements in agricultural productivity and natural resource management can be achieved in two ways: First, through the provided transfers and the relaxation of capital 
IJCCSM 10,1

constraints to allow food-insecure farmers to invest in agricultural inputs (Bezu and Holden, 2008), and second, through assets build under the programmes.

While there is a lack of sound research on the environmental benefits of assets built under NREGA, research on PSNP demonstrates that assets contribute to a reduction in soil loss and sedimentation as well as to improved biomass production (Subbarao et al., 2013). Increases in agricultural productivity, however, have only been documented for households who have access to PSNP as well as to technical assistance (Hoddinott et al., 2012; Berhane et al., 2011). Generally, benefits of PSNP increase when it is combined with other instruments that strengthen income-generating capacities or provide access to financial services (Berhane et al., 2011; 2014). These findings demonstrate that the effectiveness of public employment likely depends on an integrated social protection approach. Linking public works to other instruments bears the potential to promote escape out of poverty (McCord and Slater, 2015; Subbarao et al., 2013), an important objective of PSNP where the achievements have yet been limited (Berhane et al., 2011).

For NREGA, the empirical evidence shows that participation increases the share of riskier but more profitable crops. This indicates that participation reduces income uncertainties and motivates investments. Through this insurance effect, NREGA provides growth opportunities and an alternative to weather insurance (Gehrke, 2014). Further effects that can provide agricultural benefits are obtained through increasing land-related investments (Deininger and Liu, 2013). Benefits for agricultural production, however, have yet not been analysed.

A recent impact evaluation of the pilot integration of weather insurance into PSNP shows that insured farmers increased savings, the number of livestock and, in one district, got better access to loans. However, the evidence on agricultural investments and the contribution of labour-for-insurance to income diversification is limited (OXFAM, 2014). More generally, evidence on an increase in farm or non-farm income could yet not be identified (Weldegebriel and Prowse, 2013). But empirical research shows that the probability to start non-farm activities increases with access to PSNP (Berhane et al., 2014; 2011). Yet, as results indicate that PSNP increases the sale of natural resources as an income source, this gives reason for concern: The intensive use of natural resources may negatively affect climate vulnerability in the long term (Weldegebriel and Prowse, 2013).

Crucial in the context of climate variability and change is whether the provision of labour is correlated with changes in rainfall. Research focusing on the Indian state Andhra Pradesh finds that the number of workdays provided under NREGA varies considerably with rainfall variability and related income shocks. This can even be demonstrated if labour demand is not fully met by the provision of work under the programme (Gehrke, 2014; Johnson, 2009). Participation also increases at a national level after negative rainfall shocks (Zimmermann, 2013). This indicates that households can at least partly compensate agricultural losses through programme participation.

The limited literature focusing on the effects of public work programmes on migration underlines that programmes have the largest welfare benefits for trapped populations or for households without access to informal risk sharing networks (Morten, 2015). Programmes can generally influence migration decisions in two directions:

(1) Additional household income could be used to cover expenses on migration as a way of income diversification (Johnson and Krishnamurthy, 2010).

(2) Alternatively, and quite the opposite, programmes can reduce temporary ruralurban migration as demonstrated by research on NREGA (Devi et al., 2011; Imbert and Papp, 2014; Ravi et al., 2013). 
A reduction in temporary migration is observed in states where NREGA is successfully implemented in terms of labour supply. People chose working under NREGA as an alternative to migrate and research indicates that beneficiaries would even chose to work more under the scheme if they were provided with additional work (Imbert and Papp, 2014).

Despite their benefits, both programmes face several implementation challenges which undermine their effectiveness. Key challenges include the quality of assets and the timeliness of payments (Subbarao et al., 2013). Further problems NREGA is facing include delayed or non-provision of work, duplicate job cards, non-existent or unfinished assets, the leakage of funds and a lack of focus on the needs of the poor (Aakella, 2015; Kamath, 2010). Tackling these challenges is a key precondition for social protection to effectively achieve its objectives of improving livelihood security and contributing to addressing climate-induced migration.

Research further indicates that public work programmes only provide a temporary safety net and are often confronted with the trade-off between the timely provision of labour and high-quality assets (Ravi and Engler, 2015). This does not necessarily undermine their potential as a strategy to address climate-induced migration, but underlines that it can only be part of a more comprehensive climate risk management approach.

\section{Social protection addressing climate-induced migration}

Climate change exacerbates the drivers of temporary and permanent migration, such as food insecurity, income shocks or deteriorating livelihood opportunities. As the empirical evidence shows, social protection can be an effective instrument to address these threats. However, benefits are not generated automatically. Programmes must be designed and implemented in a way that they explicitly address climate risks. This section explores how social protection, or in particular public employment schemes, can address migration associated with climate-related extremes and slow-onset changes in both rural and urban areas. It identifies key characteristics of effective social protection programmes and derives important policy implications for addressing climate-induced migration.

\subsection{Social protection and extreme-weather events}

Short-term migration of household members or the whole household is a common strategy to smooth negative income shocks caused by extreme events. To give examples, empirical evidence shows that distress migration increases after negative rainfall shocks (Morten, 2015; Kleemans, 2015), as a consequence of heat stress, floods and landslides (Mueller et al., 2014; Robalino et al., 2015), as well as of cyclones (Lu et al., 2016) and crop failures (Gray and Mueller, 2012a). In 2015, 14.7 million people were internally displaced by weather-related extremes (Bilak et al., 2016). However, research also demonstrates that the increase in migration is only modest after extreme events, for which social protection and relief efforts are considerably large (Mueller et al., 2014; Gray and Mueller, 2012a; Palmer and Smith, 2014; Tacoli, 2009). This demonstrates that social protection already plays an important role in addressing distress migration. Similar to the provision of credit (Kleemans, 2015), social protection offers an alternative risk management strategy.

Distress migration reduces the opportunity for households to save for migration and to use migration as an investment (Kleemans, 2015; Johnson and Krishnamurthy, 2010; Warner and Afifi, 2014). Considering the projected impacts of climate change this has important policy implications: In regions where climate-related extreme events are projected to become more intense or frequent, such as droughts and heavy precipitation events in India (Vinke et al., 2016) and Ethiopia (Weldegebriel and Prowse, 2013), households may be forced to migrate more often. This further diminishes their resources to migrate temporarily 
IJCCSM

10,1

or permanently if climate risks become intolerable. Barriers to migration increase. As demonstrated in some states of India where NREGA is successfully implemented, public work programmes can be an effective instrument to prevent costly distress migration through the provision of work and income. Public employment schemes can thus make migration a choice in the long term.

Population groups, which lack resources or face barriers to migrate, use alternative coping strategies to overcome income shortages. This can only be evaluated as a successful strategy when it helps overcome a crisis without jeopardizing future livelihood security (Paul and Routray, 2011; Warner and Afifi, 2014). Climate-related shocks, however, can force vulnerable households to make use of unsustainable coping strategies, such as reducing food intake, selling land, livestock or other crucial assets (Johnson and Krishnamurthy, 2010; Warner and Afifi, 2014; Warner and van der Geest, 2013). Hence, non-migration should be as much a policy concern as migration (Adams and Adger, 2013; Foresight, 2011; Gemenne, 2011). According to the empirical evidence on PSNP, social protection can reduce the use of maladaptive coping strategies. Improved food intakes have also been demonstrated for NREGA.

Cash for work programmes can further support recovery and reconstruction after extreme events and play an important role in disaster risk reduction and prevention (Coirolo et al., 2013; Paul and Routray, 2011; Johnson and Krishnamurthy, 2010). As an example, the majority of NREGA funds are spent on assets such as water conservation, drought proofing and renovation of traditional water bodies. These assets have the potential to reduce the impacts of drought though empirical evidence is still limited (Kumar, 2015). PSNP verifiably generates environmental benefits reducing the negative effects of droughts. A crucial precondition is the completion and quality of assets as well as the integration of climate risks into their design (Kuriakose et al., 2013). This requires climate risk assessments as well as capacity development for local engineers.

Social protection can thus function as a safety net for households affected by climaterelated extremes and facing the risk of displacement (Coirolo et al., 2013; Foresight, 2011; Johnson and Krishnamurthy, 2010; Paul and Routray, 2011). It addresses market failures, such as the lack of insurance or access to credit needed to prevent or recover from extremes (Dercon, 2011). Through their insurance effect public employment schemes offer an alternative coping strategy to migration, which is demonstrated, for example, by Imbert and Papp (2014). They can also prevent the deterioration of household resources, linked to future livelihood security and the ability to migrate. Johnson (2009) underlines that public work programs also cover landless agricultural labourers in contrast to crop insurance. Research on NREGA further suggests that effective social protection schemes especially benefit marginalized population groups who are the most vulnerable to climate change and likely lack the resources to migrate.

But benefits are not generated automatically: Social protection programmes must be explicitly designed to address distress migration effectively. Key features are predictability and adequacy of support (Béné et al., 2014), a high degree of flexibility in terms of targeting as well as the timing of transfers (Coirolo et al., 2013; Dercon, 2011; Johnson, 2009; Kuriakose et al., 2013). More importantly, social protection programmes must be informed by early warning systems, such as weather and climate risk indices, that allow to quickly identify affected regions and population groups as well as the extent of support needed (Kuriakose et al., 2013). In the medium and longer term, climate risk analyses can support the identification of areas of high risk (or hotspots) where severe climatic and environmental changes may likely affect human migration patterns (Piguet, 2010). This can help design social protection and adaptation strategies. 
To successfully reduce distress migration, social protection schemes must provide transfers without delay and address the specific needs of the poor in the aftermath of extremes. Lengthy bureaucratic processes for getting access to social safety nets exacerbate emergencies and fail in smoothing income. The design of NREGA offers a good example: The programme provides work for rural households in need within 15 days (Ministry of Rural Development, Government of India, 2012). However, evaluations of the programme in different Indian states indicate that implementation of NREGA is lagging behind its potential (Imbert and Papp, 2014; Johnson, 2009). Especially, delays in wage payments undermine the target of achieving food security (Subbarao et al., 2013). Further, support to address urgent needs after extreme-weather events is usually needed within the first three days. This requires even higher levels of flexibility (Coirolo et al., 2013).

Programmes must also be accessible for a broad range of target groups, as climate change not only affects below the poverty-line (BPL) households, which often have exclusive access to social protection. Climate change may drive non-BPL households without risk management options into poverty (Chaudhuri, 2003; Coirolo et al., 2013; Davies et al., 2009). Consequently, targeting, which generally is a major challenge in developing countries due to poor administration (Coirolo et al., 2013; Johnson and Krishnamurthy, 2010), should not be limited to BPL households or potential climate migrants. Such an approach most likely excludes a large proportion of vulnerable households and transitory poor.

NREGA, as an example, is accessible for every rural household willing to provide manual labour at the minimum wage. This self-targeting mechanism offers great flexibility (Dercon, 2011). The minimum wage acts as a barrier for households having the chance to earn higher wages in private labour markets. This strategy prevents adverse selection and reduces targeting costs (Reddy, 2010). PSNP, in contrast, uses a targeting approach combining geographic and community-based selection criteria. According to the empirical research, PSNP effectively reaches poor and food-insecure households (Coll-Black et al., 2011). A contingency fund further allows to flexibly increase support (Subbarao et al., 2013). Few programmes yet provide the flexibility to broaden coverage or increase transfers in the case of weather and climate shocks (Dercon, 2011). NREGA, as one of the rare cases, has repeatedly increased the maximum number of labour days provided to households. This has been applied in drought-affected states, last in 2016. However, even though additional days are granted and funds provided by the government, the statistics show that with a national average of just 47 days per household in the financial year 2015/2016 (Ministry of Rural Development, Government of India, 2016), NREGA has not even achieved its goal to provide 100 days of labour. This questions the effectiveness and relevance of granting additional days of labour.

A summary of the potential benefits of public work programmes to address the risk of climate- and weather-related extremes is provided in Figure 1.

\subsection{Social protection and slow-onset changes}

The literature to date mostly focuses on climate extremes and short-term migration (Hunta et al., 2015). Slow-onset changes lack attention in the current research and policy arena, but they will be an important driver for future migration and more likely cause permanent migration (Adams and Adger, 2013; Adger et al., 2014; Martin, 2013; Maystadt and Mueller, 2012; Tacoli, 2009). Social protection can reduce the pressure to migrate as well as facilitate costlier long-term migration. This can be mainly achieved through increasing household income but also through supporting destination areas (Béné et al, 2014; Dercon, 2011; 


\section{IJCCSM \\ 10,1}

54

Figure 1.

Migration-relevant benefits of public work programmes

\begin{tabular}{|c|c|c|}
\hline $\begin{array}{l}\text { Continuum of } \\
\text { potential } \\
\text { migration } \\
\text { outcomes }\end{array}$ & $\begin{array}{l}\text { Climate (change)-related } \\
\text { driver/multiplier of risk }\end{array}$ & $\begin{array}{l}\text { Potential benefits of public work } \\
\text { programmes }\end{array}$ \\
\hline $\begin{array}{l}\text { No migration due } \\
\text { to barriers }\end{array}$ & $\begin{array}{l}\text { Recurrent climate-related } \\
\text { extremes - increase in } \\
\text { frequency/intensity }\end{array}$ & $\begin{array}{l}\text { - Reduction of maladaptive } \\
\text { coping strategies and loss of } \\
\text { income } \\
\text { - Consumption smoothing } \\
\text { - Enable and facilitate } \\
\text { migration }\end{array}$ \\
\hline $\begin{array}{l}\text { Short-term } \\
\text { distress } \\
\text { migration } \\
\text { (potentially } \\
\text { cyclical and } \\
\text { erosive) }\end{array}$ & : & 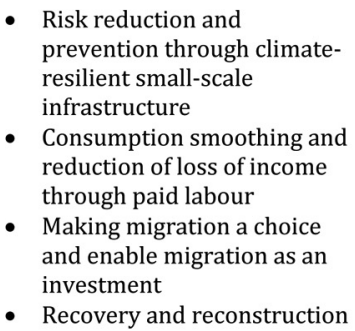 \\
\hline $\begin{array}{l}\text { Long(er)-term } \\
\text { migration that } \\
\text { increases } \\
\text { vulnerability in } \\
\text { destination areas }\end{array}$ & & $\begin{array}{l}\text { - Risk reduction and } \\
\text { prevention through climate- } \\
\text { resilient infrastructure } \\
\text { - Economic integration } \\
\text { through short-term } \\
\text { employment } \\
\text { - Social cohesion through } \\
\text { community-based planning }\end{array}$ \\
\hline $\begin{array}{l}\text { Long- } \\
\text { term/permanent } \\
\text { (economic) } \\
\text { migration }\end{array}$ & $\begin{array}{l}\text { Slow-onset changes } \\
\text { continuously deteriorating } \\
\text { livelihood opportunities }\end{array}$ & $\begin{array}{l}\text { - Assets and infrastructure } \\
\text { addressing climate change } \\
\text { impacts and improving } \\
\text { adaptive capacities } \\
\text { - Insurance effect enabling } \\
\text { profitable investments } \\
\text { - Enable migration as an } \\
\text { investment }\end{array}$ \\
\hline
\end{tabular}

Source: Authors own

Johnson and Krishnamurthy, 2010). Being able to migrate is usually not identified as a key capacity to adapt to climate change. Only recently, it is getting more attention in the context of slow, irreversible climatic changes (Béné et al., 2014).

In theory and partly documented by the empirical evidence presented in this paper, public employment programmes can increase household income through four different channels: first, through the provision of paid employment; second, through increasing rural wages; third, through increased agricultural production as an effect of productivity increasing assets; and finally, through the insurance effect of an employment guarantee stimulating investments (Gehrke, 2014; Klonner and Oldiges, 2014).

Low wage income from public employment, however, is often directly used for consumption (McCord and Slater, 2015). To enable productive investments or savings for 
migration, wage levels must be sufficiently high. This, however, may have significant implications for national budgets provided for social protection.

The existing literature suggests that productivity improvements can only be achieved by an integrated social protection approach. Negative climate change impacts will make this even more difficult as many regions are threatened by decreasing agricultural yields (Olsson et al., 2014). Public employment can support adaptation responses through building rural infrastructure that explicitly addresses negative climate change impacts. Building check dams, terracing or percolation tanks to improve watershed management (Kumar, 2015) or soil fertility (Uphoff and Jagannath, 2014) are good examples from PSNP and NREGA. An integral aspect is that assets are built in a way that they achieve expected benefits under changing climatic conditions (Weldegebriel and Prowse, 2013). Decreasing freshwater availability projected for both regions (Gemenne, 2011; Tacoli, 2009; Vinke et al., 2016), as an example, needs to be considered in asset design. Currently, hardly any programme is "climate-proof" and considers long-term climatic changes. Though aiming at the same objective of vulnerability reduction, adaptation and social protection programmes are often developed and implemented in silos (Davies et al., 2013). In India, for example, it is key to expand water storage facilities to use projected increases in peak monsoon river flow and smooth increasing changes in monsoon precipitation (Vinke et al., 2016). NREGA could play a key role in this task but does yet not consider climate risks explicitly.

Interviews with beneficiaries indicate that NREGA already generates benefits for agriculture, such as water access, reduced runoff, fertilizer use and water-logging (Ranaware et al., 2015). However, these impacts are yet not substantiated by empirical evidence and assets often remain unfinished or badly maintained. Again, the quality of assets plays a crucial role for the materialization of medium and long-term benefits.

As the empirical research on NREGA demonstrates, the insurance effect of an employment guarantee can enable switching to more profitable crops. But transfers of public work programmes are often too low for farmers to invest in productive assets and further improve agricultural productivity or diversify income sources (Béné et al., 2014; Johnson et al., 2013). This is underlined by the findings that PSNP alone does not improve agricultural productivity and has limited success in supporting graduation out of poverty. This requires a combination of different policy and social protection instruments, such as public employment programmes under which climate-resilient assets are constructed, cash transfers and skills training. A more integrated approach to social protection and climate risk management is therefore required.

Building resilience against the impacts of climate change may reduce but not prevent the pressure to migrate (Foresight, 2011). More importantly, providing small-scale assets through public employment in areas affected severely by slow-onset changes or manifesting livelihoods that are extremely sensitive to climate change impacts will not be a sustainable solution (Johnson et al., 2013). Programmes must encourage livelihood diversification and the spreading of risk. This includes the facilitation of migration as a risk reduction strategy (Béné et al., 2014; Johnson et al., 2013; Martin, 2010). Especially in areas that cannot be protected from sea-level rise, regular flooding or storm surges, or that suffer from a severe lack of water migration should be a key approach to climate risk management. For this purpose, it is crucial that climate projections are taken into account when designing and implementing social protection schemes.

An overview of the potential benefits of public work programmes to address migration associated with slow-onset changes as well as their interaction with climate and weather extremes is presented in Figure 1. Table I identifies the criteria for effective programme design. 


\section{IJCCSM \\ 10,1}

\section{6}

Predictability and timeliness of support

Adequacy of support

Flexibility in targeting (regionally and level of income)

Table I.

Effective programme design

Relevance, quality and climate-proofing of assets and infrastructure

Source: Authors own

\section{Effectiveness criteria \\ Policy options}

Community-based planning to ensure needs orientation Capacity development for (local) engineers to ensure quality and climate-resilience of assets and infrastructure Incorporation of climate risks into asset and infrastructure selection and design based on climate risk assessments

Contingency funds or sovereign risk insurance providing additional resources in due time

Rapid provision of additional work, e.g. based on contingency or community development plans

Rapid provision of transfers, e.g. via bank accounts or additional in-kind transfers

Needs-based support (amount and duration of transfers) based on rapid needs assessments, e.g. through contingency funds or sovereign risk insurance allowing to scale up support in case of extremes

Integration of climate risk indices considering potential regional impacts of climate variability and change for earlywarning

Self-selection or geographic targeting

\subsection{Social protection in urban destination areas}

Urbanization trends in developing countries are projected to continue due to population growth and rural-urban migration, which is likely to increasingly become an important adaptation strategy (Foresight, 2011; Maystadt and Mueller, 2012; Revi et al., 2014; Tacoli, 2009). Robalino et al. (2015), for example, demonstrate that hydro-meteorological events, such as floods and landslides, significantly increase migration to metropolitan areas in Costa Rica.

At the same time, urban areas, especially coastal cities, are highly exposed to the impacts of climate change (Davies et al., 2009; Foresight, 2011; Maystadt and Mueller, 2012; Revi et al., 2014; Rosenzweig et al., 2011; Tacoli, 2009). In particular, informal and poorer settlements are at high risk from climate and weather extremes. They lack basic infrastructure and adaption efforts and are often home to migrants (Revi et al., 2014; Tacoli, 2009; Walter, 2015). Urban migrants are already and will be among the most vulnerable population groups. But both research and policies do yet not pay enough attention to urban areas, neglecting an important dimension of climate risk (ODI, 2016; Tacoli, 2009). Key policies and measures addressing climate risks for urban migrants as well as the urban poor include access to basic services and social protection, as well as climate-resilient and inclusive infrastructure (Foresight, 2011; Maystadt and Mueller, 2012; Tacoli, 2009; Walter, 2015).

Though research on urban areas as destination areas as well as places of origin is limited (Hunta et al., 2015; Obokata et al., 2014), the literature suggests that social protection can be an important instrument to support adaptation in urban areas. The introduction of public employment programmes for the construction of community assets that provide access to water, drainage, sanitation and waste management could generate substantial benefits (Dercon, 2011), not only for migrants but also for the resident population. At the time, public employment programmes provide temporary income opportunities for migrants and the urban poor and facilitate economic 
integration. Temporary employment and community planning of infrastructure can further promote social cohesion (Revi et al., 2014; Subbarao et al., 2013). Basic infrastructure can reduce the vulnerability of informal settlements to the risk of climate change impacts (Revi et al., 2014). In addition to community assets, social protection can also support the provision of assets to migrants, such as land and housing in safe areas (Johnson and Krishnamurthy, 2010). An important precondition is to better plan the expansion of cities and avoid settlements in areas of high risk. This requires a climate-sensitive and decentralized urban planning approach (Tacoli, 2009).

To date, however, most public work programmes focus exclusively on rural areas. An expansion or introduction of social protection to urban areas is highly needed (Coirolo et al., 2013; Dercon, 2011). Ensuring the quality and considering the impacts of climate change and weather extremes in the design of assets is as much a challenge as in rural areas. But it also provides an opportunity for climate-sensitive and more inclusive urban planning.

In addition to public employment schemes, cash transfers and skills development could play an important role in ensuring food security, enabling migrants to enter urban labour markets and reducing the vulnerability of migrants and the urban poor (Johnson and Krishnamurthy, 2010; Revi et al., 2014). The potential benefits and criteria for an effective policy design in urban destination areas are also summarized in Figure 1 and Table I.

\section{Conclusion}

Based on conceptual arguments and empirical evidence, this paper argues that social protection can be part of a proactive approach to managing climate-induced migration. On the one hand, social protection can reduce distress migration and erosive coping strategies. On the other hand, it can make migration a choice in the long term. In particular, public employment programmes can create assets that enhance livelihood opportunities and explicitly address the impacts of climate change in both rural and urban areas and in places of origin and destination.

Effective protection strategies require flexible targeting and timely provision of transfers to smooth income and consumption fluctuations as well as to address chronic and transitory poverty affected and caused by climate change. Social protection programmes must be designed in a way that they explicitly address climate change impacts from climate-related extremes as well as from slow-onset changes and the causes of livelihood insecurity driving migration. Urban areas must be included in social protection programmes due to increasing rural-urban migration, the high level of exposure of urban areas to climate risks and vulnerability of migrants living in informal settlements.

Still, social protection is no silver bullet to solve the problem of climate-induced migration or non-migration. Not all aspects of livelihood insecurity can and have to be addressed by a single approach. It does also not offer a solution for maintaining indigenous culture often strongly affected or even disrupted by climate change (Jacob et al., 2010; Olsson et al., 2014). Hence, an effective approach needs to combine different policy instruments to support protection, adaptation and migration. Most importantly, focusing solely on reducing migration is unlikely to increase climate resilience. Policies must consider both planning and facilitating migration as an adaptation strategy.

Social protection programmes serve as important temporary safety nets and provide fast-start support - depending on their design and effective implementation - for different climate-induced migration outcomes. They can play a role in long-term adaptation strategies by providing small-scale rural and urban infrastructure, by their insurance effect stimulating productive investments and by potential increases in rural 
IJCCSM 10,1

income. They cannot, however, sustainably and explicitly address all climate changerelated risks and should be designed as part of a comprehensive climate risk management approach.

Limited government capacities and fiscal feasibility may impede the expansion and effective implementation of social protection (Subbarao et al., 2013; Barrientos et al., 2012). Developing countries may need further support not only for designing and adjusting programme designs to current and projected climate change impacts but also for effectively implementing social protection schemes.

While this paper mainly builds on empirical evidence from two large-scale public employment schemes, future research should consider other social protection programmes and instruments as well as their benefits in urban areas. In particular, long-term and resilience-building effects of social protection need to be analysed empirically. This especially applies to the benefits of assets built under employment programmes and their contribution to climate change adaptation.

Further, a better theoretical understanding of migration decisions is needed (Warner and Afifi, 2014; Palmer and Smith, 2014; Piguet, 2012). This requires theoretical and empirical research on migration choice models as well as on the economics of climate migration both from a macro- and micro-economic perspective. More empirical research, especially based on longitudinal data, is needed on the barriers to and causes for different types of migration, on the characteristics determining the propensity of households or individuals to migrate, on the interaction of climate and environmental drivers of migration with existing public support programmes, as well as on migration patterns in different areas of the world prone to climate change impacts (Black et al, 2011; Gray and Mueller, 2012a; Martin, 2013; Obokata et al, 2014; Palmer and Smith, 2014).

A better understanding would allow designing more specific adaptation responses to climate-induced migration and non-migration complementing social protection programmes. The complexity of the various drivers of migration decisions as well as the diversity of migration outcomes requires a combination of case and context-specific measures. Social protection provides a generic nevertheless effective approach to deal with different forms of migration. It can be an important starting point to address acute distress, to initiate adaptation in rural and urban areas, and to facilitate migration as an adaptation strategy.

\section{References}

Aakella, K.V. (2015), “Technology in governance - case of MGNREGS in Andhra Pradesh”, Economic \& Political Weekly, Vol. 13, pp. 24-26.

Adams, H. (2016), "Why populations persist: mobility, place attachment and climate change", Population and Environment, Vol. 37 No. 4, pp. 429-448.

Adams, H. and Adger, W.N. (2013), "Changing places, migration and adaptation to climate change", in Sygna, L., O'Brien, K. and Wolf, J. (Eds), The Changing Environment for Human Security: Transformative Approaches to Research, Policy, and Action, Routledge-Earthscan, London, pp. 413-423.

Adger, W.N., Pulhin, J.M., Barnett, J., Dabelko, G.D., Hovelsrud, G.K., Levy, M. and Vogel, C.H. (2014), "Human security", in Field, C.B., Barros, V.R., Dokken, D.J., Mach, K.J., Mastrandrea, M.D., Bilir, T.E., White, L.L. (Eds), Climate Change 2014: Impacts, Adaptation, and Vulnerability, Part A: Global and Sectoral Aspects, Contribution of Working Group II to the Fifth Assessment Report of the Intergovernmental Panel on Climate Change, Cambridge University Press, Cambridge and New York, NY, pp. 755-791. 
Barnett, J. and Webber, M. (2010), "Accommodating migration to promote adaptation to climate change”, Policy Research Working Paper No. 5270, The World Bank, Washington, DC, April 2010.

Barrientos, A., Hickey, S., Hulme, D. and Nin, M. (2012), "Social protection in Sub-Saharan Africa: getting the politics right", World Development, Vol. 40 No. 1, pp. 163-176.

Béné, C., Cannon, T., Davies, M., Newsham, A. and Tanner, T. (2014), "Social protection and climate change", OECD Development Co-operation Working Papers 16, OECD Publishing, June 2014.

Berhane, G., Gilligan, D.O., Hoddinott, J., Kumar, N. and Taffesse, A.S. (2014), "Can social protection work in Africa? The impact of Ethiopia's productive safety net programme", Economic Development and Cultural Change, Vol. 63 No. 1, pp. 1-26.

Berhane, G., Hoddinott, J., Kumar, N. and Taffesse, A.S. (2011), The Impact of Ethiopia's Productive Safety Nets and Household Asset Building Programme: 2006-2010, International Food Policy Research Institute, Washington, DC.

Bezu, S. and Holden, S. (2008), “Can food-for-work encourage agricultural production?”, Food Policy, Vol. 33 No. 6, pp. 541-549.

Bilak, L., Cardona-fox, G., Ginnetti, J., Rushing, E.J., Scherer, I., Swain, M. and Yonetani, M. (2016), "Global Report on Internal Displacement", Internal Displacement Monitoring Centre (IDMC), Geneva.

Black, R., Bennett, S.R.G., Thomas, S.M. and Beddington, J.R. (2011), "Climate change: migration as adaptation", Nature, Vol. 478 No. 7370, pp. 447-449.

Bohra-Mishra, P., Oppenheimer, M. and Hsiang, S.M. (2014), "Nonlinear permanent migration response to climatic variations but minimal response to disasters", Proceedings of the National Academy of Sciences of the United States of America, Vol. 111 No. 27, pp. 9780-9785.

Chaudhuri, S. (2003), Assessing Vulnerability to Poverty: Concepts, Empirical Methods and Illustrative Examples, Department of Economics Columbia University, Columbia, available at: http:// econdse.org/wp-content/uploads/2012/02/vulnerability-assessment.pdf (accessed 18 November 2016).

Clarke, D. and Dercon, S. (2009), "Insurance, credit and safety nets for the poor in a world of risk", DESA Working Paper 81.

Coirolo, C., Commins, S., Haque, I. and Pierce, G. (2013), "Climate change and social protection in Bangladesh: are existing programmes able to address the impacts of climate change?", Development Policy Review, Vol. 31, pp. 74-90.

Coll-Black, S., Gilligan, D.O., Hoddinott, J., Kumar, N., Taffesse, A.S. and Wiseman, W. (2011), "Targeting food security interventions when 'everyone is poor': the case of Ethiopia's productive safety net programme", ESSP II Working Paper 24, May 2011.

Davies, M., Béné, C., Arnall, A., Tanner, T., Newsham, A. and Coirolo, C. (2013), "Promoting resilient livelihoods through adaptive social protection: lessons from 124 programmes in South Asia”, Development Policy Review, Vol. 31 No. 1, pp. 27-58.

Davies, M., Guenther, B., Leavy, J., Mitchell, T. and Tanner, T. (2009), "Climate change adaptation, disaster risk reduction and social protection: complementary roles in agriculture and rural growth?”, IDS Working Paper 320, February 2009.

De Weerdt, J. and Hirvonen, K. (2013), "Risk sharing and internal migration”, Policy Research Working Paper 6429, The World Bank, Washington, DC, April 2013.

Deininger, K. and Liu, Y. (2013), "Welfare and poverty impacts of India's national rural employment guarantee scheme evidence from Andhra Pradesh", IFPRI Discussion Paper 01289, September 2013.

Dercon, S. (2011), "Social protection, efficiency and growth", CSAE Working Paper WPS/2011-17, University of Oxford, September 2011. 
IJCCSM 10,1

Devi, T.S., Balasubramanian, R. and Kumar, B.G. (2011), "Employment, income and labour supply decision of rural households: an economic analysis of MGNREGS in Tamil Nadu", Agricultural Economics Research Review, Vol. 24, pp. 473-484.

Felgentreff, C. and Geiger, M. (2013), "Einleitung: Klima und Umwelt als Determinanten räumlicher Mobilität?", in Felgentreff, C. and Geiger, M. (Eds), Migration und Umwelt, Institut für Migrationsforschung und Interkulturelle Studien, Osnabrück, pp. 7-17.

Feng, S., Krueger, A.B. and Oppenheimer, M. (2010), "Linkages among climate change, crop yields and Mexico - US cross-border migration", Proceedings of the National Academy of Sciences of the United States of America, Vol. 107 No. 32, pp. 14257-14262.

Foresight (2011), Migration and Global Environmental Change: Future Challenges and Opportunities, The Government Office for Science, London.

Gehrke, E. (2014), "An employment guarantee as risk insurance? Assessing the effects of the NREGS on agricultural production decisions", BGPE Discussion Paper 152, Friedrich-Alexander-University Erlangen-Nuremberg, Erlangen, May 2014.

Gemenne, F. (2011), "Climate-induced population displacements in a $4^{\circ} \mathrm{C}+$ world", Philosophical Transactions of the Royal Society, Vol. 369 No. 1934, pp. 182-195.

Gentilini, U. and Omamo, S.W. (2011), "Social protection 2.0: exploring issues, evidence and debates in a globalizing world”, Food Policy, Vol. 36 No. 3, pp. 329-340.

Gomilova, M. (2016), "Finding opportunities to combat the climate change migration crisis: the potential of the 'adaptation approach", Pace Environmental Law Review, Vol. 33 No. 2, pp. 105-156.

Gray, C.L. and Mueller, V. (2012a), "Natural disasters and population mobility in Bangladesh", Proceedings of the National Academy of Sciences, Vol. 109 No. 16, pp. 6000-6005.

Gray, C.L. and Mueller, V. (2012b), "Drought and population mobility in rural Ethiopia”, World Development, Vol. 40 No. 1, pp. 134-145.

Gray, C.L. and Wise, E. (2016), "Country-specific effects of climate variability on human migration", Climatic Change, Vol. 135 Nos 3/4, pp. 555-568.

Hoddinott, J., Berhane, G., Gilligan, D.O., Kumar, N. and Taffesse, A.S. (2012), "The impact of Ethiopia's productive safety net programme and related transfers on agricultural productivity", Journal of African Economies, Vol. 21 No. 5, pp.761-786.

Holst, R., Yu, X. and Gruen, C. (2013), "Climate change, risk and grain yields in China", Journal of Integrative Agriculture, Vol. 12 No. 7, pp. 1279-1291.

Hunta, L.M., Luna, J.K. and Norton, R.N. (2015), "Environmental dimensions of migration", Annual Review of Sociology, Vol. 41 No. 1, pp. 377-397.

Imbert, C. and Papp, J. (2014), "Short-term migration, rural workfare programs and urban labor markets: evidence from India”, Center for Economic Policy Research.

International Organization for Migration (IOM) (2004), International Migration Law - Glossary on Migration, IOM, Geneva.

Ionesco, D., Mokhnacheva, D. and Gemenne, F. (2017), The Atlas of Environmental Migration, Routledge, Abingdon, OX and New York, NY.

Jacob, C., McDaniels, T. and Hinch, S. (2010), "Indigenous culture and adaptation to climate change: Sockeye Salmon and the St'át'imc people”, Mitigation and Adaptation Strategies for Global Change, Vol. 15 No. 8, pp. 859-876.

Jha, R., Bhattacharyya, S. and Gaiha, R. (2011), "Social safety nets and nutrient deprivation: an analysis of the national rural employment guarantee program and the public distribution", Journal of Asian Economics, Vol. 22 No. 2, pp. 189-201.

Johnson, C., Dulal, H.B., Prowse, M., Krishnamurthy, K. and Mitchell, T. (2013), "Social protection and climate change: emerging issues for research, policy and practice", Development Policy Review, Vol. 31, pp. 2-18. 
Johnson, C.A. and Krishnamurthy, K. (2010), “Dealing with displacement: can 'social protection' facilitate long-term adaptation to climate change?”, Global Environmental Change, Vol. 20 No. 4, pp. 648-655.

Johnson, D. (2009), "Can workfare serve as a substitute for weather insurance? The case of NREGA in Andhra Pradesh", Centre for Micro Finance Working Paper Series 32, September 2009.

Jülich, S. (2011), "Drought triggered temporary migration in an East Indian village", International Migration, Vol. 49.

Kamath, R. (2010), "National rural employment guarantee act: an effective safety net?", IIMB Management Review, Vol. 22 Nos 1/2, pp. 42-55.

Kelley, C.P., Mohtadi, S., Cane, M.A., Seager, R. and Kushnir, Y. (2015), "Climate change in the fertile crescent and implications of the recent Syrian drought", Proceedings of the National Academy of Sciences, Vol. 112 No. 11, pp. 3241-3246.

Klaiber, H.A. (2014), "Migration and household adaptation to climate: a review of empirical research", Energy Economics, Vol. 46, pp. 539-547.

Kleemans, M. (2015), "Migration choice under risk and liquidity constraints", presentation at the 2015 Agricultural \& Applied Economics Association and Western Agricultural Economics Association Annual Meeting, San Francisco, CA, (July 26-28),

Klein, R.J.T., Midgley, G.F., Preston, B.L., Alam, M., Berkhout, F.G.H., Dow, K. and Shaw, M.R. (2014), "Adaptation opportunities, constraints, and limits", in Field, C.B., Barros, V.R., Dokken, D.J., Mach, K.J., Mastrandrea, M.D., Bilir, T.E., White, L.L. (Eds), Climate Change 2014: Impacts, Adaptation, and Vulnerability, Part A: Global and Sectoral Aspects. Contribution of Working Group II to the Fifth Assessment Report of the Intergovernmental Panel on Climate Change, Cambridge University Press, Cambridge, and New York, NY, pp. 899-943.

Klonner, S. and Oldiges, C. (2014), "Safety Net for India's poor or waste of public funds? poverty and welfare in the wake of the world's largest job guarantee program", Department of Economics Discussion Paper Series 564, University of Heidelberg, March 2014.

Kniveton, D.R., Smith, C.D. and Black, R. (2012), "Emerging migration flows in a changing climate in dryland Africa”, Nature Climate Change, Vol. 2 No. 6, pp. 444-447.

Kothari, J. (2014), "A social rights model for social security: learnings from India”, Verfassung in Recht und Übersee, Vol. 47 No. 1, pp. 5-21.

Koubi, V., Spilker, G. and Schaffer, L. (2013), "Environmental degradation and migration”, paper prepared for presentation at the annual meeting of the American Political Science Association, Chicago, IL, August 2013.

Kumar, N. (2015), "Exploring the potential of MGNREGA for the revitalization of rainfed agriculture in India", International Journal of Agricultural Science and Research, Vol. 5 No. 1, pp. 59-66.

Kuriakose, A.T., Heltberg, R., Wiseman, W., Costella, C., Cipryk, R. and Cornelius, S. (2013), "Climateresponsive social protection”, Development Policy Review, Vol. 31 No. S2, pp. 19-34.

Lieuw-Kie-Song, M. (2010), "Green jobs for the poor: why a public employment approach is needed now”, International Policy Center for Inclusive Growth 105, February 2010.

Lu, X., Wrathall, D.J., Roe, P., Wetter, E., Iqbal, A., Qureshi, T. and Bengtsson, L. (2016), “Unveiling hidden migration and mobility patterns in climate stressed regions: a longitudinal study of six million anonymous mobile phone users in Bangladesh", Global Environmental Change, Vol. 38, pp. 1-7.

McCord, A. and Slater, R. (2015), "Social protection and graduation through sustainable employment", IDS Bulletin, Vol. 46 No. 2, pp. 134-144.

McLeman, R. (2013), "Developments in modelling of climate change-related migration", Climatic Change, Vol. 117 No. 3, pp. 599-611.

Mallick, B. and Vogt, J. (2014), "Population displacement after cyclone and its consequences: empirical evidence from coastal Bangladesh", Natural Hazards, Vol. 73 No. 2, pp. 191-212. 
IJCCSM

10,1

Martin, S.F. (2010), Climate Change, Migration and Adaptation, The German Marshall Fund of the United States, Washington, DC, (June 2010),

Martin, S.F. (2013), "Environmental change and migration: what we know", Migration Policy Institute Policy Brief 2, September 2013.

Maystadt, J.-F. and Mueller, V. (2012), "Environmental migrants: a myth?”, IFPRI Research Brief, 18.

Mbaye, L.M. and Zimmermann, K.F. (2015), “Environmental disasters and migration”, IZA Discussion Paper No. 9349, Institute for the Study of Labor, Bonn, September 2015.

Ministry of Rural Development, Government of India (2012), MGNREGA Sameeksha - An Anthology of Research Studies on the Mahatma Gandhi National Rural Employment Guarantee Act, 2005 2006-2012, Ministry of Rural Development, Government of India, Delhi.

Ministry of Rural Development, Government of India (2015), "MGNREGA Public Data Portal", available at: http://mnregaweb4.nic.in/netnrega/dynamic2/DynamicReport_new4.aspx (accessed 9 July 2015).

Ministry of Rural Development, Government of India (2016), “Average days of employment provided per household”, available at: http://164.100.129.6/netnrega/MISreport4.aspx?fin_year=20152016\&rpt=RP (accessed 22 January 2016).

Morten, M. (2015), “Internal migration and social safety nets in India”, available at: http://siepr.stanford. edu (accessed 15 July 2015).

Mueller, V., Gray, C. and Kosec, K. (2014), "Heat stress increases long-term human migration in rural Pakistan", Nature Climate Change, Vol. 4 No. 3, pp. 182-185.

Obokata, R., Veronis, L. and McLeman, R. (2014), "Empirical research on international environmental migration: a systematic review", Population and Environment, Vol. 36, pp. 111-135.

ODI (2016), Climate-Induced Migration and Displacement: Closing The Policy Gap, Briefing, Overseas Development Institute, London, (October 2016),

Olsson, L., Opondo, M., Tschakert, P., Agrawal, A., Eriksen, S.H., Ma, S., Perch, L.N. and Zakieldeen, S. A. (2014), "Livelihoods and poverty", in Field, C.B., Barros, V.R., Dokken, D.J., Mach, K.J., Mastrandrea, M.D., Bilir, T.E., White, L.L. (Eds), Climate Change 2014: Impacts, Adaptation, and Vulnerability, Part A: Global and Sectoral Aspects, Contribution of Working Group II to the Fifth Assessment Report of the Intergovernmental Panel on Climate Change, Cambridge University Press, Cambridge and New York, NY, pp. 793-832.

OXFAM (2014), Managing Risks to Agricultural Livelihoods - Impact Evaluation of the HARITA Project in Ethiopia (2009-2012), Oxfam America, Oxford.

Palmer, P.I. and Smith, M.J. (2014), "Model human adaptation to climate change", Nature, Vol. 512 No. 7515 , pp. 365-366.

Panda, A. (2013), "Climate variability and the role of access to crop insurance as a social-protection measure: insights from India”, Development Policy Review, Vol. 31 No. S2, pp. 579-573.

Paul, S.K. and Routray, J.K. (2011), "Household response to cyclone and induced surge in coastal Bangladesh: coping strategies and explanatory variables", Natural Hazards, Vol. 57 No. 2, pp. 477-499.

Piguet, E. (2010), "Linking climate change, environmental degradation, and migration: a methodological overview", Wiley Interdisciplinary Reviews: Climate Change, Vol. 1 No. 4, pp. 517-524.

Piguet, E. (2012), "Migration: the drivers of human migration", Nature Climate Change, Vol. 2 No. 6, pp. 400-401.

Piguet, E. (2013), "From 'primitive migration' to 'climate refugees': the curious fate of the natural environment in migration studies", Annals of the Association of American Geographers, Vol. 103 No. 1, pp. 148-162. 
Ranaware, K., Das, U., Kulkarni, A. and Narayanan, S. (2015), "MGNREGA works and their impacts - a study of Maharashtra", Economic \& Political Weekly, Vol. 13, pp. 53-61.

Ravi, S. and Engler, M. (2009), Workfare in Low Income Countries: An Effective Way to Fight Poverty? The Case of NREGS in India, SEW-HSG Universitaet St. Gallen, Varnbüelstrasse.

Ravi, S. and Engler, M. (2015), "Workfare as an effective way to fight poverty: the case of India's NREGS”, World Development, Vol. 67, pp. 57-71.

Ravi, S. Kapoor, M. and Ahluwalia, R. (2013), "The Effects of Rural Employment Guarantee on Urbanization", available at: http://ssrn.com/abstract=2134778 (accessed 18 November 2016).

Reddy, D.N. (2010), "National rural employment guarantee as social protection”, IDS Bulletin, Vol. 41 No. 4, pp. 63-75.

Revi, A., Satterthwaite, D.E., Aragón-Durand, F., Corfee-Morlot, J., Kiunsi, R.B.R., Pelling, M., Roberts, D.C. and Solecki, W. (2014), "Urban areas", in Field, C.B., Barros, V.R., Dokken, D.J., Mach, K.J., Mastrandrea, M.D., Bilir, T.E., White, L.L. (Eds), Climate Change 2014: Impacts, Adaptation, and Vulnerability, Part A: Global and Sectoral Aspects, Contribution of Working Group II to the Fifth Assessment Report of the Intergovernmental Panel on Climate Change, Cambridge University Press, Cambridge and New York, NY, pp. 535-612.

Robalino, J., Jimenez, J. and Chacon, A. (2015), "The effect of hydro-meteorological emergencies on internal migration”, World Development, Vol. 67, pp. 438-448.

Rosenzweig, C., Hammer, S.A., Solecki, W.D. and Mehrotra, S. (2011), Climate Change and Cities. First Assessment Report of the Urban Climate Change Research Network, Cambridge University Press, Cambridge and New York, NY.

Subbarao, K., del Ninno, C., Andrews, C. and Rodríguez-Alas, C. (2013), Public Works as a Safety Net, Design, Evidence, and Implementation, The World Bank, Washington, DC.

Tacoli, C. (2009), "Crisis or adaptation? Migration and climate change in a context of high mobility", Environment \& Urbanization, Vol. 21 No. 2, pp. 513-525.

UNFCCC (2014), "Initial two-year workplan of the executive committee of the Warsaw international mechanism for loss and damage", available at: http://unfccc.int/adaptation/workstreams/ loss_and_damage/items/8805.php (accessed 29 June 2015).

UNFCCC (2016a), "Technical meeting action area (6): migration, displacement and human mobility recommendations", available at: http://unfccc.int/files/adaptation/groups_committees/loss_and_ damage_executive_committee/application/pdf/technical_meeting_recommendations.pdf

UNFCCC (2016b), "Report of the executive committee of the Warsaw international mechanism for loss and damage associated with climate change impacts", available at: http://unfccc.int/resource/ docs/2016/sb/eng/03.pdf (accessed 20 January 2016).

Uphoff, N. and Jagannath, P. (2014), "MGNREGA: investment in soil systems asset creation", NewsResearch, pp. 46-48.

Vinke, K., Martin, M.A., Adams, S., Baarsch, F. and Martin, M.A. (2016), "Climatic risks and impacts in South Asia: extremes of water scarcity and excess", Regional Environmental Change, pp. 1-15.

Walter, P. (2015), "Floods and rural urban migration in Bangladesh", in Gemenne, F., Zickgraf, C. and Ionesco, D. (Eds), The State of Environmental Migration 2015, A Review of 2014, Internationl Organization for Migration (IOM), Geneva, pp. 51-64.

Warner, K. and Afifi, T. (2014), "Where the rain falls: evidence from 8 countries on how vulnerable households use migration to manage the risk of rainfall variability and food insecurity", Climate and Development, Vol. 6 No. 1, pp. 1-17.

Warner, K. and van der Geest, K. (2013), "Loss and damage from climate change: local-level evidence from nine vulnerable countries", International Journal of Global Warming, Vol. 5 No. 4, pp. 367-386. 
IJCCSM

10,1

64
Weldegebriel, Z.B. and Prowse, M. (2013), "Climate-change adaptation in Ethiopia: to what extent does social protection influence livelihood diversification?”, Development Policy Review, Vol. 31 No. 2 , pp. 35-56.

Zhao, Q., Yu, X., Wang, X. and Glauben, T. (2014), “The impact of parental migration on children? School performance in rural China", China Economic Review, Vol. 31, pp. 43-54.

Zimmermann, L. (2013), Why Guarantee Employment? Evidence from a Large Indian Public-Works Program, University of Michigan, Michigan, (October 2013).

\section{Corresponding author}

Susanne Schwan can be contacted at: susanne.schwan@stud.uni-goettingen.de

For instructions on how to order reprints of this article, please visit our website: www.emeraldgrouppublishing.com/licensing/reprints.htm

Or contact us for further details: permissions@emeraldinsight.com 